\title{
Effects of Local Watershed Land Use on Water Quality in Mid-Atlantic Coastal Bays and Subestuaries of the Chesapeake Bay
}

\author{
Thomas E. Jordan ${ }^{1}$ • Donald E. Weller ${ }^{1}$ • Carey E. Pelc ${ }^{1}$
}

Received: 21 October 2016/Revised: 22 May 2017 / Accepted: 8 August 2017 /Published online: 23 August 2017

(C) The Author(s) 2017, corrected publication 2019

\begin{abstract}
Nutrient inputs have degraded estuaries worldwide. We investigated the sources and effects of nutrient inputs by comparing water quality at shallow $(<2 \mathrm{~m}$ deep) nearshore (within $200 \mathrm{~m}$ ) locations in a total of 49 Chesapeake subestuaries and Mid-Atlantic coastal bays with differing local watershed land use. During July-October, concentrations of total nitrogen (TN), dissolved ammonium, dissolved inorganic N (DIN), and chlorophyll $a$ were positively correlated with the percentages of cropland and developed land in the local watersheds. TN, DIN, and nitrate were positively correlated with the ratio of watershed area to subestuary area. Total phosphorus (TP) and dissolved phosphate increased with cropland but were not affected by developed land. The relationships among $\mathrm{N}, \mathrm{P}$, chlorophyll $a$, and land use suggest $\mathrm{N}$ limitation of chlorophyll $a$ production from July-October. We compared our measurements inside the subestuaries to measurements by the Chesapeake Bay Program in adjacent estuarine waters outside the subestuaries. TP and dissolved inorganic $\mathrm{P}$ concentrations inside the subestuaries correlated with concentrations outside the subestuaries. However, water quality inside the subestuaries generally differed from that in adjacent estuarine waters. The concentration of nitrate was lower inside the subestuaries, while the concentrations of other forms of N, TP, and chlorophyll $a$ were higher. This suggests that shallow nearshore waters inside the subestuaries import nitrate while exporting other forms of $\mathrm{N}$ as well as TP and chlorophyll $a$. The importance of local land use and the
\end{abstract}

Communicated by Mark J. Brush

Thomas E. Jordan

jordanth@si.edu

1 Smithsonian Environmental Research Center, 647 Contees Wharf Road, Edgewater, MD 21037, USA distinct biogeochemistry of shallow waters should be considered in managing coastal systems.

Keywords Estuaries · Watershed land use · Nitrogen · Phosphorus $\cdot$ Chlorophyll $\cdot$ Eutrophication

\section{Introduction}

Human activities have greatly increased discharges of the plant nutrients nitrogen $(\mathrm{N})$ and phosphorus $(\mathrm{P})$ to estuarine and coastal waters (Howarth et al. 1996; Caraco and Cole 1999; Castro et al. 2003), which has stimulated primary production and caused widespread eutrophication (Nixon 1995; Cloern 2001). In stratified estuaries, eutrophication can lead to persistent oxygen depletion beneath the pycnocline, creating "dead zones" (e.g., Hagy et al. 2004; Diaz and Rosenberg 2008; Doney 2010; Howarth et al. 2011). In shallow waters, eutrophication can produce short-term hypoxia at night or during warm, cloudy weather (Tyler et al. 2009), thus degrading nearshore habitats (Brady and Targett 2013). Decreases in light availability with increased production of phytoplankton and epiphytic algae have led to widespread declines in submerged aquatic vegetation and associated fauna (Bologna and Heck 1999; Orth et al. 2006, 2017; Waycott et al. 2009). Nutrient enrichment can directly impact tidal wetlands by enhancing the spread of invasive species such as the common reed Phragmites australis (Silliman and Bertness 2004; Kettenring et al. 2015; Sciance et al. 2016). Nutrient enrichment can also reduce root production, potentially undermining wetland bank integrity (Deegan et al. 2012) and slowing marsh accretion, which may reduce marsh resilience to rising sea level (Langley et al. 2009).

The consequences of nutrient pollution in nearshore waters can be significant for estuarine food webs, which can depend 
on tidal wetlands and submerged aquatic vegetation as a structural and energetic base (Edgar 1990; Edgar and Shaw 1995; Paterson and Whitfield 2000). Vegetated and unvegetated shallows are both feeding grounds and refuges from predation, enhancing energy flow to higher trophic levels (Dittel et al. 1995; Miller et al. 1996; Clark et al. 2003) and making nearshore estuarine waters critical habitats for many fisheries as well as important seasonal habitats for migratory species (Erwin 1996; Beck et al. 2001).

Our study focused on shallow nearshore waters in Chesapeake Bay and nearby mid-Atlantic coastal bays. Eutrophication is a critical problem in Chesapeake Bay leading to a seasonally anoxic dead zone in its deepest stratified channels and widespread losses of submerged aquatic vegetation (Boesch et al. 2001; Kemp et al. 2005; Orth et al. 2010). To mitigate this problem, a multistate effort coordinated by the Chesapeake Bay Program is working to meet a federal mandate to reduce nutrient inputs (the "pollution diet" or TMDL; USEPA 2010). Eutrophication is also a problem in the coastal bays where limited exchange of water with the ocean can exacerbate nutrient pollution, leading to blooms of macro algae and harmful phytoplankton (Wazniak et al. 2007; Glibert et al. 2007).

Nutrient inputs to Chesapeake Bay and the coastal bays come from point sources such as sewage treatment plants and from non-point sources including urban and agricultural lands as well as atmospheric deposition (Eshleman and Sabo 2016). Non-point source pollution by nutrients and sediments from croplands and animal management areas is generally higher than non-point source pollution from developed lands, but developed lands release more non-point nutrients and sediments than natural lands, like forest or wetlands (Beaulac and Reckhow 1982; Jordan et al. 1997a, b, 2003; Liu et al. 2000).

To target nutrient reduction efforts, it is useful to know which land uses supply nutrients and which nutrient limits primary productivity. In fresh water, $\mathrm{P}$ is usually the nutrient limiting primary production, but in saline coastal water $\mathrm{N}$ is usually limiting (e.g., Howarth and Marino 2006). In Chesapeake Bay, either $\mathrm{N}$ or $\mathrm{P}$ can be limiting depending on the salinity and season (Jordan et al. 1991; Fisher et al. 1992, 1999). The Chesapeake Bay program has targeted both $\mathrm{N}$ and $P$ for reduction (USEPA 2010).

Shallow waters abound in Chesapeake Bay, which has mean depth of only $6.5 \mathrm{~m}$ although its surface area is $11,500 \mathrm{~km}^{2}$ (Kemp et al. 2005). Formed from a drowned river valley, Chesapeake Bay is a dendritic complex of estuaries nested within estuaries. The largest river entering the Bay is the Susquehanna, which supplies about half the total freshwater inflow and is the dominant freshwater source of the upper main stem of the Bay. Many small subestuaries join to the main stem of the Bay or to other larger subestuaries, such as the lower Potomac River. Managing nutrients and their ecological impacts in a subestuary requires knowing whether the nutrients are coming from the local watershed or from mixing with tidal waters outside of the subestuary. In one small subestuary, the Rhode River, nitrogen and chlorophyll concentrations were mainly influenced by the water outside the estuary, which is dominated by Susquehanna River discharge, while phosphorus inputs came from the local watershed (Jordan et al. 1991).

The mid-Atlantic coastal bays are shallow lagoons separated from the ocean by barrier beaches. Average depths of the Maryland coastal bays range from 0.7-1.2 $\mathrm{m}$ (Dennison et al. 2009), and the average depths of Delaware's Indian River and Rehoboth Bay combined is $1.7 \mathrm{~m}$ (Cerco et al. 1994). Some of the coastal bays are interconnected behind their barrier island, though these connections may be narrow with limited exchange of water between the bays (e.g., Cerco et al. 1994). Some small Maryland bays are essentially subestuaries of the larger Chincoteague Bay.

Our study was part of a larger project investigating effects of multiple stressors on tidal wetlands, submerged aquatic vegetation, benthic invertebrates, and nekton in shallow nearshore waters in mid-Atlantic estuaries (Prosser et al. this issue). The project compared habitats along different shoreline types in several Coastal Bays and Chesapeake subestuaries with watersheds that differ in their proportions of cropland and developed land. Although many factors can influence the release of $\mathrm{N}$ and $\mathrm{P}$ from watersheds, the proportions of urban and agricultural lands are often used to predict $\mathrm{N}$ and $\mathrm{P}$ releases (e.g., Jordan et al. 2003; Weller et al. 2003). Relating discharges of nutrients to proportions of land types can indicate which lands are the most important sources. Differences in relationships between proportions of source lands and nutrient releases can indicate differences in nutrient management practices, watershed hydrology, or extent of nutrient sinks in watersheds (e.g., Jordan et al. 1997a, b, c; Weller et al. 2011; Weller and Baker 2014).

We analyzed water quality in the coastal bays and Chesapeake subestuaries to address the following questions: How do watershed land uses and hydrodynamic characteristics affect concentrations of chlorophyll $a$ and forms of nitrogen and phosphorus? What controls the concentration of chlorophyll $a$ ? How does water quality in shallow nearshore water inside subestuaries differ from deeper tidal waters outside of the subestuary? Is water quality in Chesapeake subestuaries controlled by land use in the local watershed or by exchanges with tidal waters outside the subestuaries?

We expected that local land use would strongly affect subestuary water quality. We hypothesized that concentrations of nutrients and chlorophyll in the subestuaries and bays would be positively correlated with the percentages of agricultural land and developed land in their watersheds and that the effects of watershed land use would be accentuated as the ratio of watershed area to estuary area increased. Given that salinity is a tracer of the relative proportions of watershed and 
ocean derived water, we also hypothesized that salinity would be negatively correlated with concentrations of substances originating from the watershed.

\section{Methods}

\section{Study Sites}

We sampled water quality in 49 Chesapeake subestuaries and Mid-Atlantic coastal bays in Maryland, Delaware, and Virginia (Fig. 1). For simplicity, we will refer to all of these systems as subestuaries. We selected subestuaries based on salinity, shoreline types, and watershed land use. The watersheds had widely differing proportions of cropland (0.3$56.8 \%$ ) and developed land (1.2-73.4\%) (Fig. 2). Subestuaries and their and local watersheds were delineated and intersected with land cover data as described in $\mathrm{Li}$ et al. 2007 and Patrick et al. 2014. The ratio of local watershed area to subestuary area (Li et al. 2007) ranged from 1.7 to 37.9. Information about watershed land cover was obtained from the 2006 National Land Cover Data (NLCD) set derived from Landsat satellite data at a $30-\mathrm{m}$ spatial resolution (Fry et al. 2011). NLCD are now also available from 2011 (Homer et al. 2015). Among the local watersheds of our 49 subestuaries, the correlation between the 2006 and 2011 land cover percentage is greater than 0.998 for both the cropland and developed land classes, so updating to the 2011 land cover data would not meaningfully change the results of our analyses relating nutrient concentrations to cropland and developed land (below). We interpreted land cover percentages as measures of land use and refer to them as land use percentages in the rest of the paper.

For Chesapeake subestuaries, we compared our measurements of water quality inside each subestuary with
Fig. 1 The Chesapeake subestuaries and mid-Atlantic coastal bays that we sampled. The local watersheds are outlined. The stars are Chesapeake Bay program water quality monitoring sites (Olson 2012). Dominant land cover was classified as described in Patrick et al. (2014)

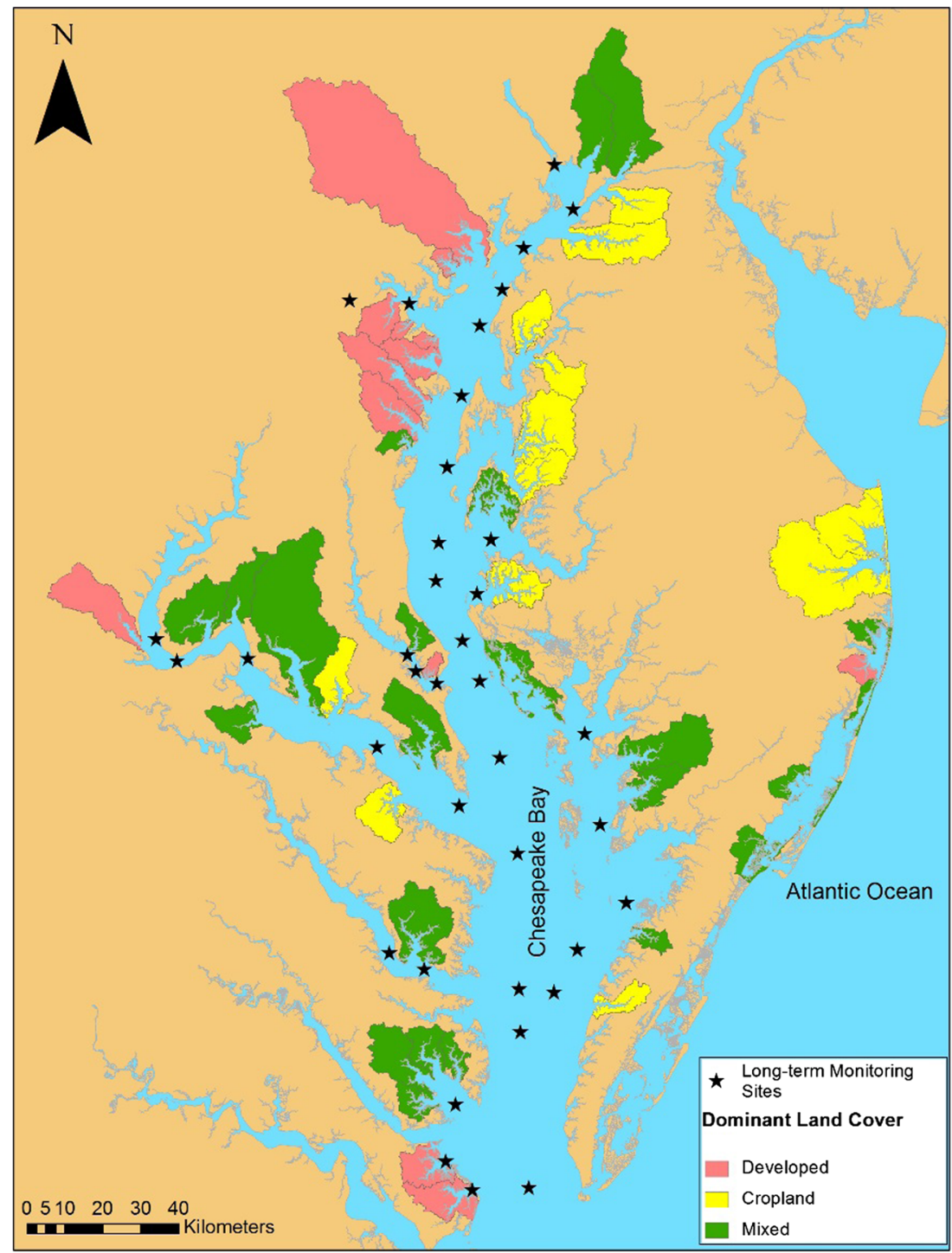




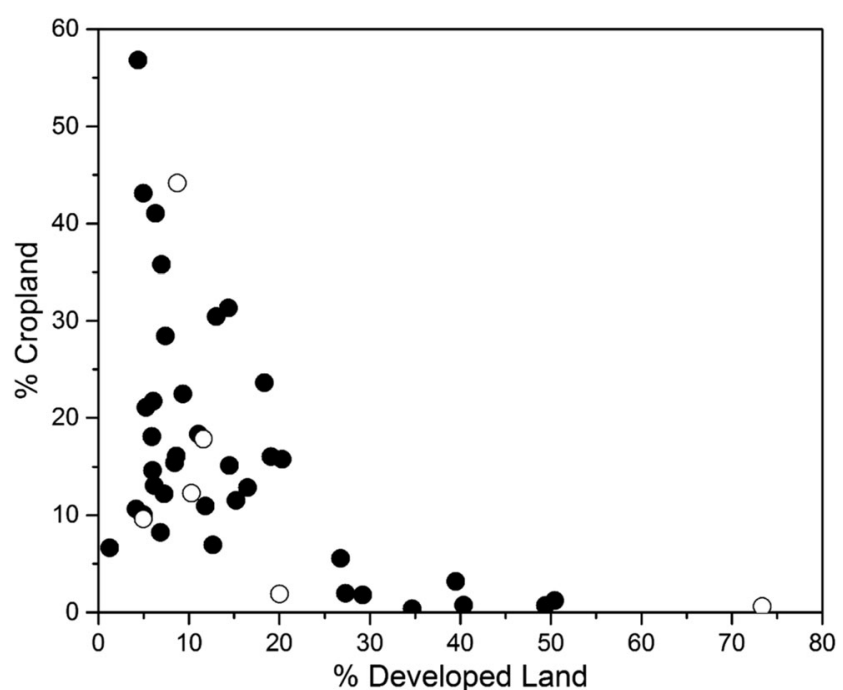

Fig. 2 The percentage of cropland versus the percentage of developed land in the sampled subestuaries. Open circles represent subestuaries that were not included in the statistical analyses because there were $<3$ samples collected for water quality analysis

Chesapeake Bay Program (CBP) measurements of water quality in adjacent tidal waters outside the subestuary (Fig. 1; Olson 2012). We selected data for the surface of the water column at the CBP monitoring stations nearest to the mouth of each subestuary. In some cases, we could use data from a CBP station just off the mouth of the subestuary. More often, we used data from two CBP stations that bracketed the location of our subestuary, averaging the CBP measurements to estimate concentrations in water adjacent to the mouth of our subestuary. We also selected the monthly CBP measurements that bracketed our samples in time, using linear interpolation to estimate concentrations outside the subestuary on the date that we sampled inside.

\section{Sampling}

Our water sampling was done to support comparative studies of nearshore habitats adjacent to different shoreline types, including beaches, tidal wetlands, bulkheads, and rip-rap revetments. Thus, the sampling locations and times were dictated by the needs of the habitat studies. Surface water was grab sampled within $200 \mathrm{~m}$ of shore in water $<2 \mathrm{~m}$ deep at various times from April-October 2010-2015. The samples were collected in acid washed Nalgene bottles and kept on ice until returned to the lab, where aliquots were filtered through a $0.45-\mu \mathrm{m}$ Millipore filter. Samples were stored in a temperature controlled cold room at $4{ }^{\circ} \mathrm{C}$ for further nutrient analysis.

\section{Nutrient and Chlorophyll Analyses}

Nitrate plus nitrite concentrations were measured on filtered samples using a cadmium reduction method. $\mathrm{pH}$ adjusted samples were passed through a $\mathrm{Cu}-\mathrm{Cd}$ gravimetric column where nitrate was reduced to nitrite. The resulting nitrite was measured colorimetrically by diazotizing with sulfanilamide and coupling with $N$-(1-napthyl)ethylenediamine dihydrochloride (APHA Method 4500NO3- E 1995). The same colorimetric method was used to analyze nitrite in samples that did not undergo nitrate reduction. Here we report the sum of nitrate plus nitrite concentration (abbreviated NO3) because nitrite was usually less than $10 \%$ of the $\mathrm{NO} 3$ when $\mathrm{NO} 3$ concentration exceeded $10 \mu \mathrm{mol} \mathrm{L}{ }^{-1}$.

Ammonium (NH4) was measured on filtered samples via oxidation to nitrite by the alkaline hypochlorite method (Strickland and Parsons 1972). The resulting nitrite was measured colorimetrically as stated above. Dissolved inorganic nitrogen (DIN) was calculated as the sum of NO3 and NH4.

Total Kjeldahl N (TKN) was determined by digestion of samples to ammonium with sulfuric acid, Hengar granules, and hydrogen peroxide (Martin 1972). The ammonium in the digestate was steam distilled and analyzed using an Astoria Pacific International (API) 300 micro-segmented flow through analyzer with digital detector (API method A303S021, APHA 1995). Total nitrogen (TN) was calculated as the sum of TKN and NO3.

Total phosphorus (TP) was determined by digesting samples to orthophosphate with perchloric acid (King 1932). The perchloric acid digestion is more laborious than the more commonly used digestions such as persulfate oxidation, but the perchloric acid method digests the widest range of phosphorus compounds and is recommended for checking the efficacy of other digestion methods (APHA Method 4500-P B 1995). Phosphate in the digested sample was analyzed by reaction with stannous chloride and ammonium molybdate (APHA Method 4500-P D 1995). Particulate TP was calculated by subtracting the filtered TP from whole TP. Dissolved orthophosphate (PO4) was determined by the same method as TP but without the digestion step.

The concentration of total suspended solids (TSS) was measured by filtering unpreserved samples through preweighed Nuclepore $0.4 \mu \mathrm{m}$ filters, dried in a vacuum sealed desiccator, and reweighed. Filtered water blanks were generally less than $5 \%$ of the TSS weights.

Whole-water samples were filtered through Whatman $\mathrm{GF} / \mathrm{F}$ filters for spectrophotometric determination of chlorophyll $a$. Filters were extracted in $10 \mathrm{ml}$ of $90 \%$ acetone, capped, and placed in a freezer. After a minimum of $24 \mathrm{~h}$ in the freezer but less than 1 week, absorbances of extracts were determined at selected wavelengths and pigment concentrations determined by the equations of Jeffrey and Humphrey (1975).

Filtered samples were measured for dissolved organic carbon (DOC) as non-purgeable organic carbon (NPOC) on a Shimadzu TOC-V CSH analyzer. 
Sample salinity was measured using a Yellow Springs Instruments (YSI) 556MPS handheld multiparameter instrument calibrated before use based on manufacturer's instructions.

\section{Data Analysis}

We used multiple regression models (lm function, $\mathrm{R}$ Development Core Team 2014) to test our primary hypotheses that the concentrations of nutrients and chlorophyll within the subestuaries would increase with the percentages of cropland and developed land in the local watershed. We also tested models that still included the percentages of cropland and developed land as well as adding one or more independent variables that might represent the effects of mixing of the water from the local watershed with water from tidal waters outside of the subestuaries. These variables were salinity in the subestuary, the ratio of the area of the local watershed to the area of the subestuary, and the concentrations of nutrients and chlorophyll outside of the subestuaries (measured by CBP, above). The regression equation is as follows:

$Y=\beta_{0}+\beta_{\mathrm{c}} C+\beta_{\mathrm{d}} D+\beta_{\mathrm{x}} X+\varepsilon$,

where $\mathrm{Y}$ is the concentration of a material inside a subestuary, $\beta_{0}$ is the model intercept, $\beta_{\mathrm{c}}$ and $\beta_{\mathrm{d}}$ are model coefficients for the proportions of cropland $(C)$ and developed land $(D)$ in the local watershed, and $\varepsilon$ is error. The optional term $\beta_{\mathrm{x}} X$ can represent the ratio of local watershed area to subestuary area, salinity in a subestuary, or the concentration of the same material outside a subestuary. We averaged concentrations across the samples from each subestuary so that each subestuary was represented by a single number in our statistical analyses.

We used type III $p$ values to judge statistical significance of independent variables, with $p<0.01$ deemed highly significant, $p<0.05$ significant, and $p<0.1$ marginally significant. We rejected models that included salinity, area ratio, or outside concentration if the type III $p$ for those variables was $>0.05$. We also used the corrected Akaike information criterion (AICc) to compare alternate models for a given response, rejecting models with an AICc value more than 4 units above the AICc of the best model (Burnham and Anderson 2002).

Because the water quality samples were collected to support other studies of shoreline habitats, sampling was distributed unevenly through time and space among the subestuaries. Our data analysis focuses mainly on samples collected from July-October. During that time, the most intensively sampled subestuary (the Rhode River) was sampled multiple times at seven locations, resulting in a total of 170-194 measurements of concentration depending on the analyte. For other subestuaries we had 1-34 measurements, with four subestuaries having only one measurement. The number of dates sampled within any subestuary other than the Rhode River ranged from 1 to 10 , with 11 subestuaries sampled on only one date. The number of sites sampled within any subestuary also ranged from 1 to 10 , with 10 subestuaries sampled at only one site. Therefore, the averages of concentrations within a subestuary were based on from 1 to 194 samples, depending on the subestuary and the analyte. Subestuaries with less than three measurements were omitted from our statistical analyses to reduce the possible influence of anomalous measurements.

To account for the influence of sample size on the uncertainty of the mean concentration estimates, we weighted each average in the statistical analysis according to the number of samples averaged. For analyses comparing only internal concentrations among subestuaries, we simply averaged samples taken at different times or locations. We had no a priori knowledge of the relative variance among different sample sites or sampling times within a subestuary, so we weighted each separate sample equally within the estuary. For example, if a subestuary was sampled at two locations on three different dates the average concentration would have a weight of six in our analysis, as would an average based on measurements from one site on six dates or from six sites on one date. There was one exception to this weighting protocol. Because the sampling of the Rhode River was much more intensive than at the other sites, average concentrations from the Rhode River could dominate the analyses if they were assigned the full weight of 170-194. Therefore, we set the weights of the Rhode River average concentrations to equal the next highest weight in our set of subestuaries, to give the Rhode River more equivalent leverage in the analysis.

We used different averaging and weighting for models testing the effects of water quality outside the subestuary on water quality inside. CBP data were not available for comparison to the coastal bays and one of the subestuaries, so the comparison of inside and outside concentrations was based on 39 Chesapeake subestuaries. Measurements outside and inside were matched according to the date sampled, so we needed to average measurements from multiple sites inside and outside the estuary before comparing them. The number of dates sampled ranged from 1 to 9 among the 39 subestuaries sampled. As before, we omitted from our statistical analysis subestuaries with fewer than three measurements, in this case fewer than three dates when concentration measurements both inside and outside the subestuary were available. Also as before, the statistical analyses were weighted by the number of dates sampled inside and outside (3-9, except for the Rhode River). Although the Rhode River was sampled on 31 dates, we set the weight of the Rhode River averages to equal nine, so it would not overly influence the analysis. 


\section{Results}

\section{Effects of Land Use and Season}

Chlorophyll concentration increased with the proportions of both cropland and developed land, but the increases were less pronounced in April-June than in July-October (Fig. 3). This suggests that the connections between estuarine eutrophication and local watershed nutrient sources are stronger after June. Because of this and because we had fewer samples from April-June, we focused our data analysis on the samples from July-October. During that time we sampled 44 of the 49 subestuaries.

For samples collected from July-October, concentrations of chlorophyll, TN, and dissolved NH4 increased significantly $(p<0.05)$ with the proportions of both cropland and developed land (Table 1, Fig. 4). TKN (the sum of organic $\mathrm{N}$ and ammonium $\mathrm{N}$ ) and DIN concentrations increased significantly with the proportion of cropland, but the relationship of TKN with the proportion of developed land was only marginally significant (Table 1). TP and PO4 increased significantly with the proportion of cropland but not with the proportion of developed land (Table 1, Fig. 4). There were no effects of land use on TSS or DOC.

\section{Effects of Watershed/Estuary Area Ratio and Salinity}

For the July-October samples, concentrations of TN, DIN, and NO3 increased significantly with increases in the ratio of watershed area to estuary area (Table 1). These increases are evident when the residual concentrations after accounting for cropland and developed land are plotted against the watershed area to estuary area ratio (Fig. 5). There was no significant effect of the area ratio on chlorophyll concentration.

Unlike the other $\mathrm{N}$ forms, $\mathrm{NH} 4$ concentration was not affected by the area ratio but increased significantly with salinity (Table 1, Fig. 6). One site, the Indian River coastal bay, had exceptionally high NH4 concentrations for its salinity and watershed land use (Fig. 6), suggesting an unusual NH4 source there. Although salinity was not a significant predictor of inside $\mathrm{NO} 3$ concentration, the outside $\mathrm{NO} 3$ concentration increased with decreasing salinity, which suggests that the larger regional watershed is the source of NO3 to tidal waters outside of the subestuary (Fig. 7).

\section{Differences Between Subestuaries and Adjacent Tidal Waters}

The quality of nearshore water inside subestuaries was generally distinct from the adjacent tidal water outside the
Fig. 3 Average chlorophyll $a$ concentrations $(\mu \mathrm{g} / \mathrm{L})$ in subestuaries versus the percentage of cropland or developed land during the periods of April-June (top) and JulyOctober 2010-2015 (bottom). To visualize the independent effect of each land use, graphs versus the percentage of cropland omit subestuaries with $>10 \%$ developed land, and graphs versus the percentage of developed land omit subestuaries with $>10 \%$ cropland. The solid lines are the indicated regressions of $y$ versus $x$, and the shaded areas are the $95 \%$ confidence limits for the predicted means. Open circles represent subestuaries that were not included in the statistical analyses because there were $<3$ samples collected for water quality analysis
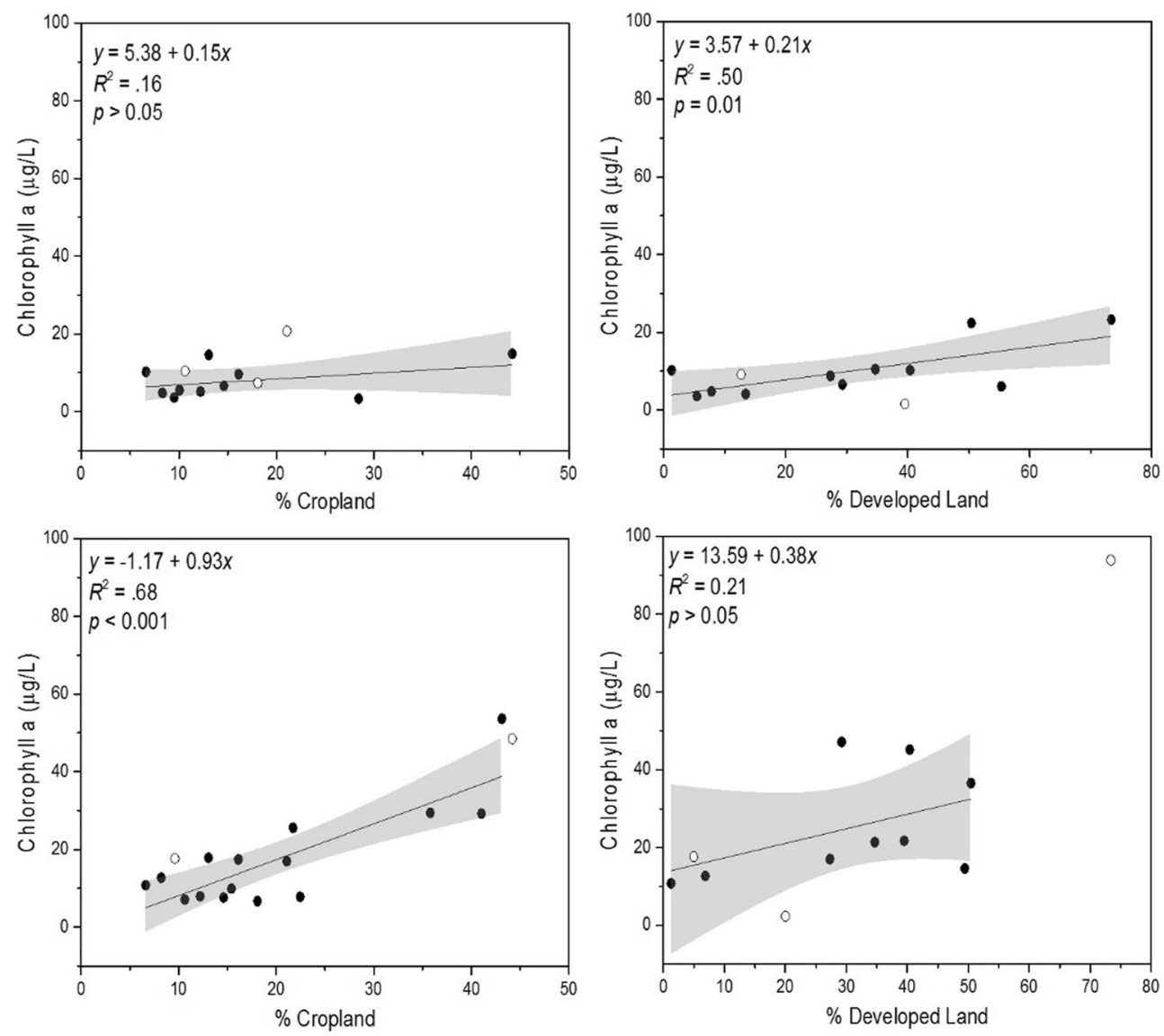
Table 1 Best models for concentrations inside the subestuaries JuneOctober. All the models compared included the percentages of both cropland and developed land as independent variables. Some models also included either salinity or the ratio of watershed to subestuary area as independent variables. The model having the lowest AICc was deemed best if its AICc was at least 4 units lower than that of any other model (i.e.,
$\Delta i>4)$. When the AICc scores of alternate models were within 4 units, the models that included either salinity or area ratio were rejected if those independent variables were not statistically significant (i.e., if $p>0.05$ ). There were 37 subestuaries compared for forms of $\mathrm{N}$ and $\mathrm{P}$ and 32 compared for chlorophyll $a$

\begin{tabular}{|c|c|c|c|c|c|c|c|c|}
\hline \multirow[b]{2}{*}{ Dep var } & \multicolumn{5}{|c|}{ Model coefficient } & \multirow[b]{2}{*}{$\mathrm{AICc}$} & \multirow[b]{2}{*}{$\Delta i$} & \multirow[b]{2}{*}{$R^{2}$} \\
\hline & Intercept & Crop & Dev & Salinity & Area ratio & & & \\
\hline $\mathrm{TN}$ & $32.5^{* *}$ & $0.721 * *$ & $0.376^{*}$ & - & $0.838 * *$ & 303 & 7.43 & 0.444 \\
\hline TKN & $39.5 * *$ & $0.621 * *$ & $0.285^{\mathrm{m}}$ & - & - & 294 & 2.27 & 0.240 \\
\hline NH4 & $-2.05^{\mathrm{ns}}$ & $0.178 * *$ & $0.101 * *$ & $0.183 * *$ & - & 167 & 9.12 & 0.475 \\
\hline NO3 & $-6.60 * *$ & $0.107^{\mathrm{m}}$ & $0.0902^{\mathrm{m}}$ & - & $0.758 * *$ & 210 & 52.1 & 0.804 \\
\hline DIN & $-5.06^{*}$ & $0.249 * *$ & $0.141^{\mathrm{m}}$ & - & $0.736^{* *}$ & 236 & 33.5 & 0.690 \\
\hline $\mathrm{TP}$ & $1.85^{*}$ & $0.083^{* *}$ & $0.0369^{\mathrm{ns}}$ & - & - & 146 & 1.51 & 0.256 \\
\hline PO4 & $-0.072^{\mathrm{ns}}$ & $0.0300 * *$ & $0.00783^{\mathrm{ns}}$ & - & - & 81.9 & 2.27 & 0.202 \\
\hline Chl $a$ & $1.43^{\mathrm{ns}}$ & $0.830^{*}$ & $0.645^{*}$ & - & - & 273 & 1.04 & 0.236 \\
\hline
\end{tabular}

${ }^{\mathrm{ns}}$ not significant $p>0.1,{ }^{\mathrm{m}}$ marginally significant $p<0.1$, * significant $p<0.05$, **highly significant $p<0.01$
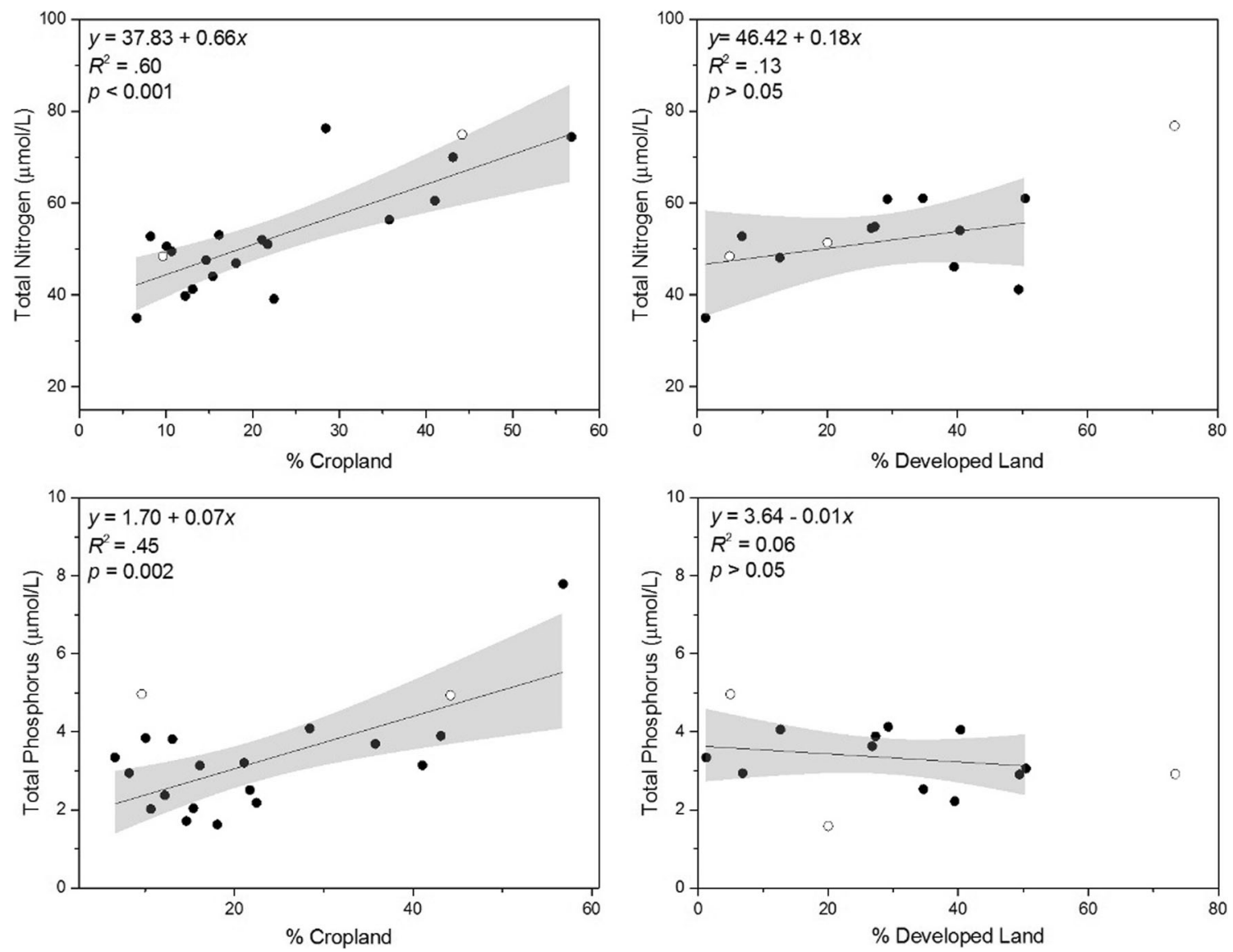

Fig. $4 \mathrm{TN}$ and TP concentration versus the percentage of cropland or developed land in the watershed. To visualize the independent effect of each land use, graphs versus the percentage of cropland omit subestuaries with $>10 \%$ developed land, and graphs versus the percentage of developed land omit subestuaries with $>10 \%$ cropland. The dotted

lines are the indicated regressions of $y$ versus $x$, and the shaded areas are the $95 \%$ confidence limits for the predicted means. Open circles represent subestuaries that were not included in the statistical analyses because there were $<3$ samples collected for water quality analysis 

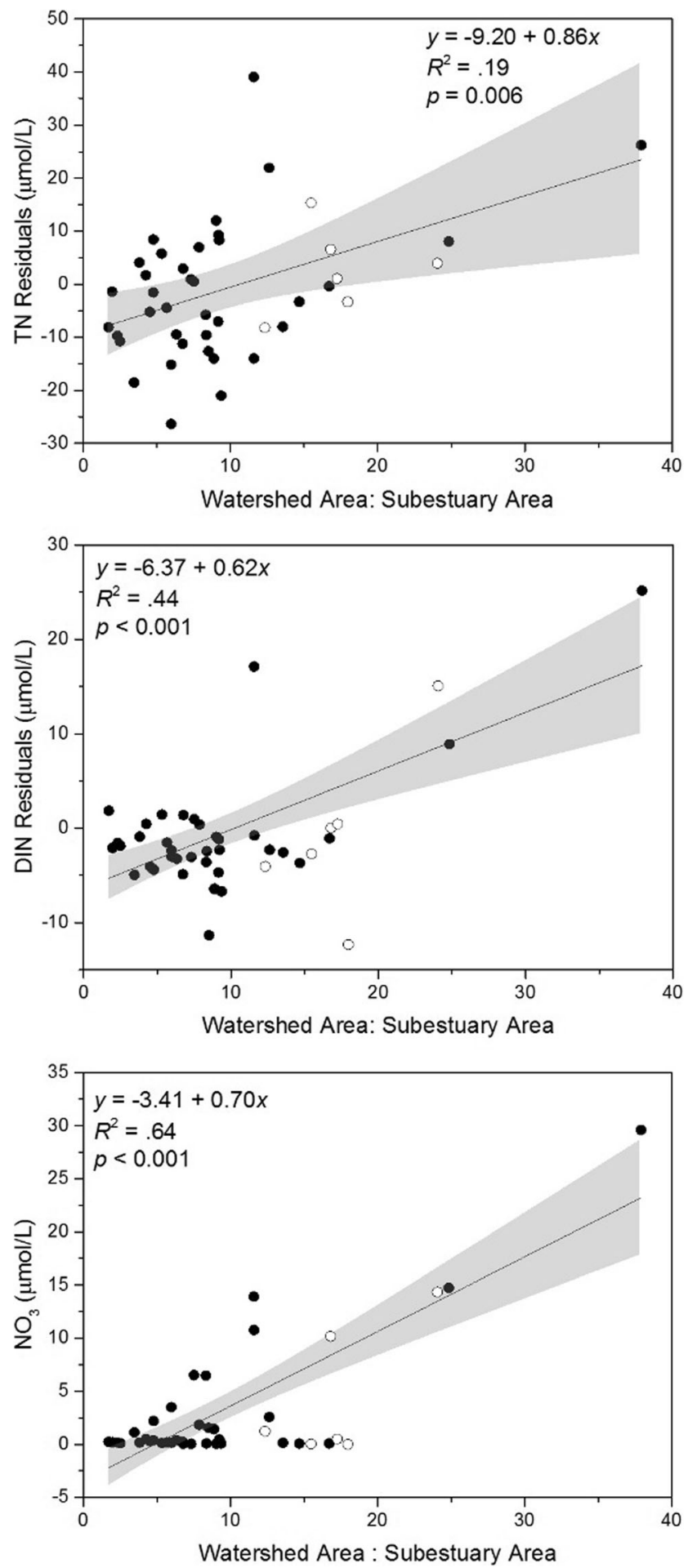

Fig. 5 The relationships of total N, DIN, and NO3 versus the ratio of the area of the watershed to the area of the subestuary. For total N and DIN, the residuals from regression models relating concentration to the percentages of cropland and developed land are plotted against the area ratio. For nitrate, the average measured concentration is plotted because the land use proportions were not significantly related to NO3 concentration. The solid lines are the indicated regressions of $y$ versus $x$, and the shaded areas are the $95 \%$ confidence limits for the predicted means. Open circles represent subestuaries that were not included in the statistical analyses because there were $<3$ samples collected for water quality analysis

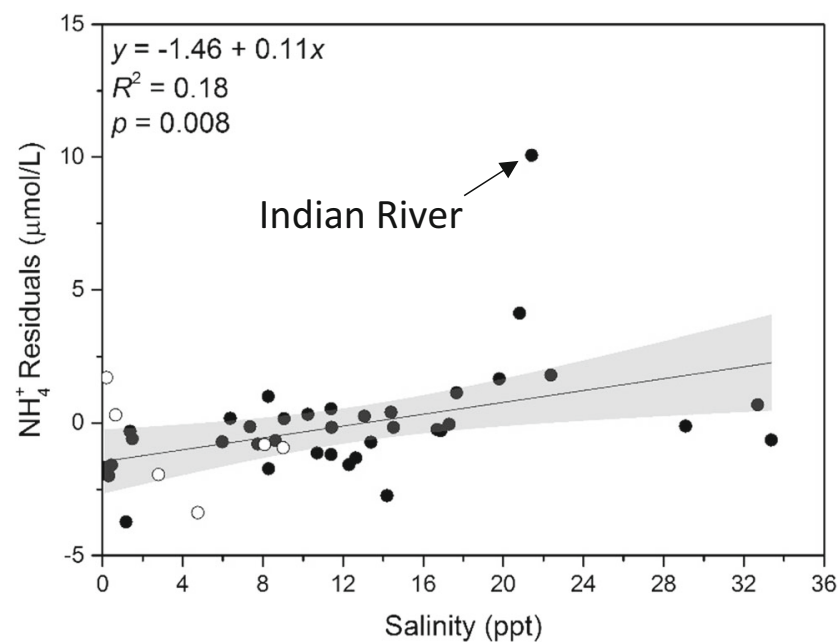

Fig. 6 The residual NH4 concentration from the model relating NH4 to the percentages of cropland and developed land versus average salinity. The solid line is the indicated regression of $y$ versus $x$, and the shaded area is the $95 \%$ confidence limits for the predicted mean. The exceptionally high point is for one of the coastal bays (Indian River, DE) that also had high NO3 and chlorophyll $a$ concentrations. Open circles represent subestuaries that were not included in the statistical analyses because there were $<3$ samples collected for water quality analysis

subestuaries. Concentrations of TP, chlorophyll, NH4, and TKN were generally much higher inside the subestuaries than outside at CBP monitoring stations (Fig. 8). In contrast, NO3 concentrations were generally higher outside than inside the subestuaries (Fig. 8). The NO3 concentration inside the Elk River was unusual in being both the highest of all the subestuaries $(33 \mu \mathrm{mol} / \mathrm{L})$ and in closely matching the outside concentration (Fig. 8). Inside total $\mathrm{N}$ was sometimes higher and sometimes lower than outside TN depending on whether NO3 or TKN forms were dominant (Fig. 8). Unlike chlorophyll and most forms of $\mathrm{N}$ and $\mathrm{P}$, salinity was similar inside and outside the subestuaries, suggesting that the inside and outside waters exchange and mix to some extent (Fig. 8). Usually, the salinity inside the subestuary was slightly less than outside, likely due to freshwater influx from the local watershed. Sometimes salinity was lower outside the subestuary, possibly reflecting freshwater inputs from larger tributaries to the main channel that had not yet mixed into the subestuary.

We used multiple regression models to assess the influence of outside concentration on inside concentration, but there was a limited number of subestuaries that had more than two dates when outside concentrations were available for statistical comparison. Inside concentrations of TP and PO4 showed significant positive correlations with outside concentrations based on data from 14 and 16 subestuaries, respectively (Table 2). In these models, the effects of land use were not significant (Table 2), although the effect of cropland was significant in models comparing 37 subestuaries without including outside concentration as 

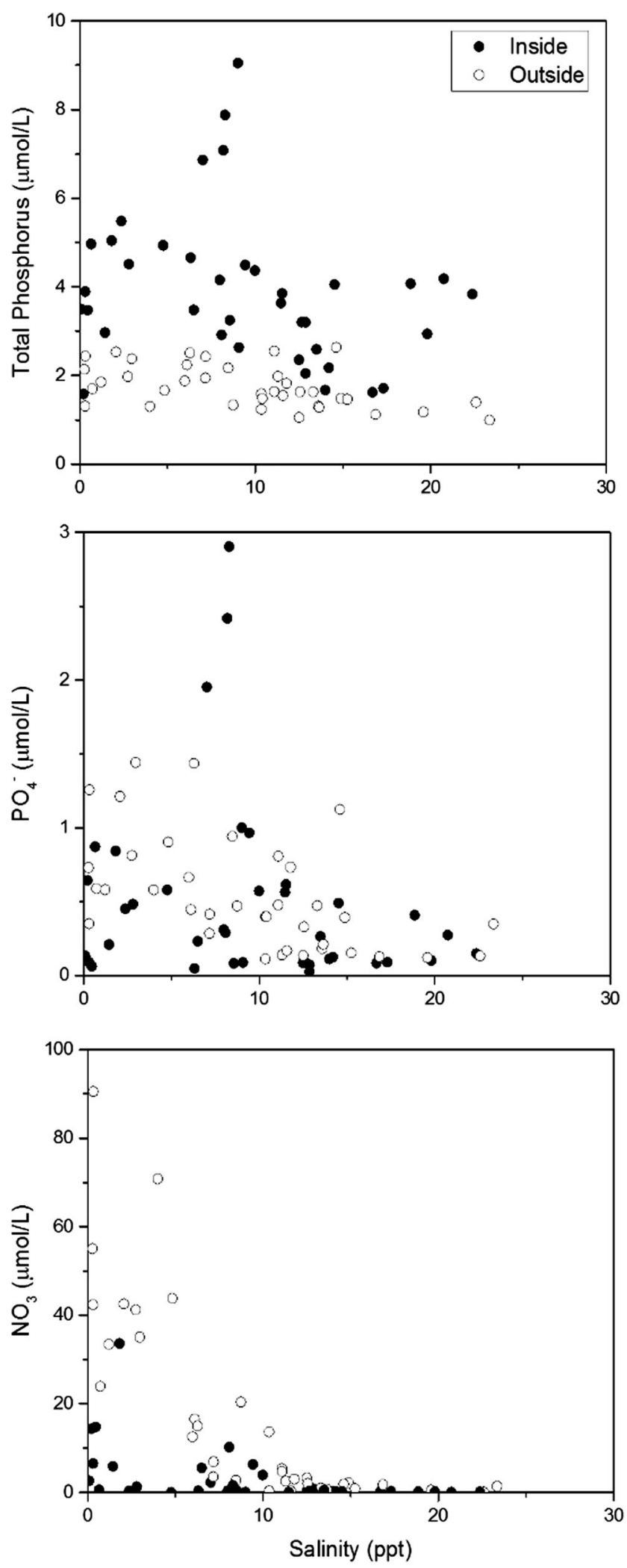

Fig. 7 Average concentrations of TP, PO4, and NO3 versus salinity inside and outside Chesapeake subestuaries an independent variable (Table 1). For chlorophyll and forms of $\mathrm{N}$, there were no significant effects of the concentration outside the subestuary on the concentration inside.

\section{Discussion}

We exploited the unique geography of the Chesapeake Bay region to study the effects of land use composition on estuarine water quality. Our findings demonstrated clear effects of land use in the local watersheds of subestuaries and effects that should be considered in nutrient management efforts. The effects of the local watersheds were strong enough to be detected with our simple sampling strategy. Our sampling also revealed effects related to exchanges between the subestuaries and adjacent tidal waters indicating the broader influence of regional watersheds. Despite the effects of estuarine mixing, water quality in shallow nearshore waters is very distinct from that of deeper waters away from shore (Fig. 8). Thus, nearshore water sampling is needed to characterize habitat quality at the land-water interface.

\section{Effects of Land Use on Estuarine Water Quality}

The positive correlations of $\mathrm{TN}, \mathrm{NH} 4$, and DIN concentrations with the percentages of cropland and developed land are consistent with land use effects observed in streams draining Coastal Plain and Piedmont watersheds near Chesapeake Bay (Jordan et al. 1997a, b, 2003). However, those studies also found land use driven increases in stream NO3 concentration, which we did not observe in our subestuaries. The lack of clear correlations between land use and NO3 concentration in the subestuaries may reflect the uptake of NO3 by phytoplankton and bacteria within the subestuaries or may indicate that the local watershed is not the only important NO3 source to a subestuary, as discussed below. The positive correlations of TP and PO4 in subestuaries with the percentage of cropland are consistent with land use effects observed for some Chesapeake streams (Jordan et al. 2003) but not for others (Jordan et al. 1997a).

Piedmont watersheds release about twice as much $\mathrm{N}$ per area of cropland as Coastal Plain watersheds (Jordan et al. 1997c). Forty of the 44 subestuaries we sampled in JulyOctober had local watersheds entirely in the Coastal Plain. The remaining four had most of their watersheds in the Piedmont, three with 15-16\% cropland and one with $2 \%$ cropland. It was not clear from these few that the elevated $\mathrm{N}$ discharges from the Piedmont croplands were reflected in subestuary water quality.

Several studies have found that the TN and TP concentrations in lakes increase with the proportions of agricultural and urban land in their watersheds (e.g., Jones et al. 2004; 

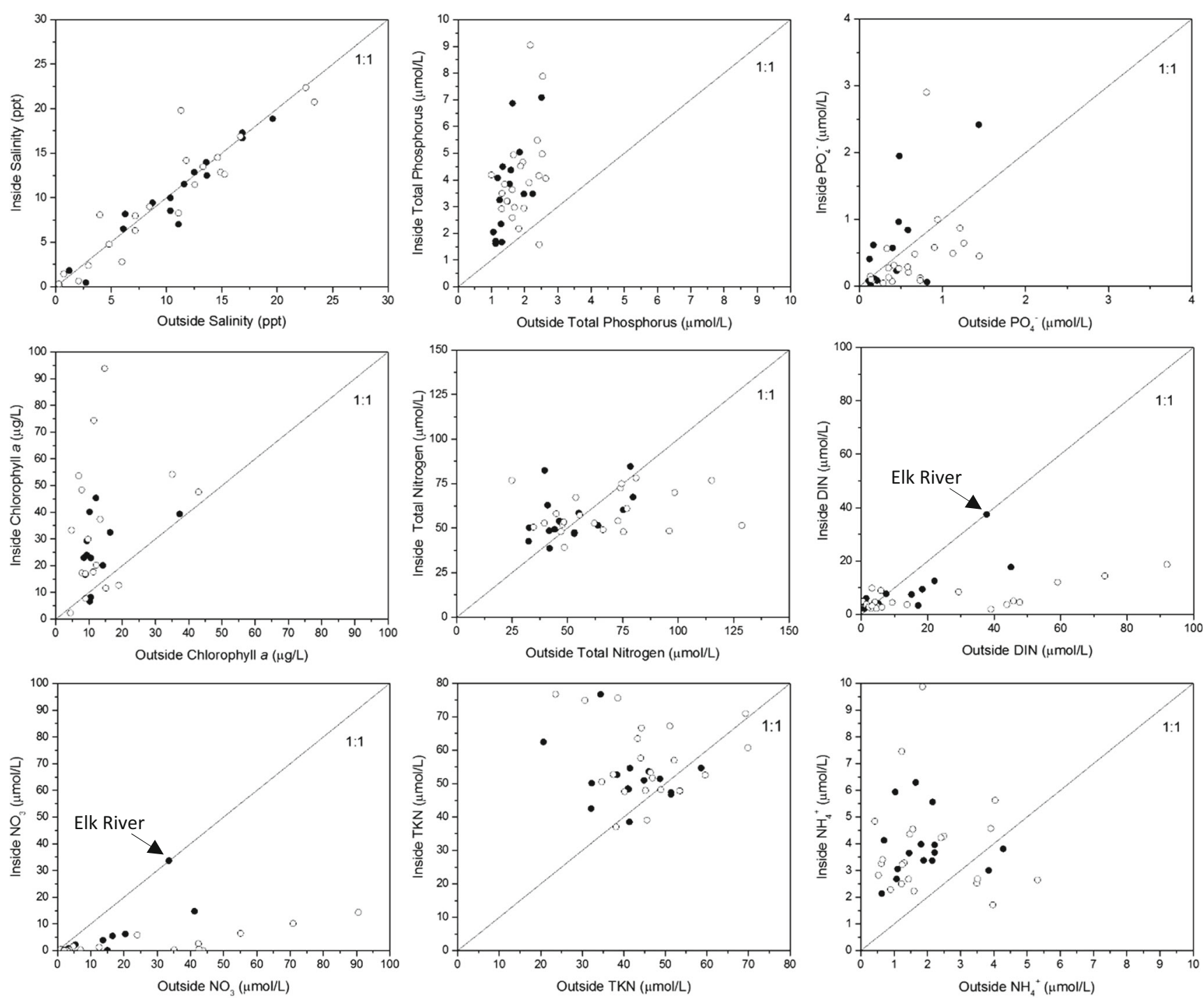

Fig. 8 The average concentration inside the subestuary versus the concentration in adjacent tidal waters outside the subestuary. Open circles represent subestuaries that were not included in the statistical analyses because there were $<3$ dates when inside and outside concentrations could be compared

Fraterrigo and Downing 2008). Some studies have found that the spatial arrangement of land types, not just their proportions in the watershed, affected lake water quality (e.g., Gemesi et al. 2011). Similarly, we have found that the presence of forested riparian buffers reduces the transmission of nitrogen from croplands to streams; however, the proportion of cropland can still account for most of the variability in nitrogen discharges from agricultural watersheds within a given physiographic province of the Chesapeake watershed (Liu et al. 2000; Weller et al. 2011, Weller and Baker 2014). Thus, our

Table 2 Best models for comparing concentrations inside and outside 38 subestuaries of Chesapeake Bay. Models with or without the outside concentration as an independent variable were compared. The model with an AICc that was four or more units lower (i.e., $\Delta i>4$ ) was selected as the best model. There were 14 subestuaries compared for TP and 16 compared for PO4

\begin{tabular}{|c|c|c|c|c|c|c|c|}
\hline \multirow[b]{2}{*}{ Dep var } & \multicolumn{4}{|c|}{ Model coefficient } & \multirow[b]{2}{*}{$\mathrm{AICc}$} & \multirow[b]{2}{*}{$\Delta i$} & \multirow[b]{2}{*}{$R^{2}$} \\
\hline & Intercept & $\%$ cropland & $\%$ developed & Outside conc. & & & \\
\hline $\mathrm{TP}$ & $0.698^{\mathrm{ns}}$ & $-0.129^{\mathrm{ns}}$ & $-0.0796^{\mathrm{m}}$ & $3.54 * *$ & 50.6 & 10.9 & 0.699 \\
\hline $\mathrm{PO} 4$ & $-0.219^{\mathrm{ns}}$ & $0.0174^{\mathrm{ns}}$ & $-0.00378^{\mathrm{ns}}$ & $1.26^{*}$ & 36.4 & 4.28 & 0.504 \\
\hline
\end{tabular}

${ }^{\mathrm{ns}}$ not significant $p>0.1,{ }^{\mathrm{m}}$ marginally significant $p<0.1$, *significant $p<0.05, * *$ highly significant $p<0.01$ 
research on Chesapeake watersheds led us to hypothesize that $\mathrm{N}, \mathrm{P}$, and chlorophyll concentrations in estuaries should increase with the proportions of cropland and developed land in their watersheds.

Although the connection between watershed land use and estuarine water quality is widely recognized (Nixon 1995; Kemp et al. 2005; Conley et al. 2009; Paerl et al. 2014), few studies have investigated this connection by comparing multiple estuaries with watersheds that differ in land use composition. One such study compared 196 estuaries throughout the contiguous USA and found that the sum of the percentages of agricultural and developed land in the watershed was the best overall predictor of an index of eutrophication (Greene et al. 2015). A study of eight subestuaries of Chesapeake Bay with widely different proportions of cropland and developed land in their watersheds did not find significant effects of either agricultural or urban land on chlorophyll concentration when the effect of each land use was tested separately (Wainger et al. 2016). In contrast, we tested the effects of the two land uses in combination and found that they both had significant effects on chlorophyll concentration in 32 subestuaries (Table 1), which included seven of the eight studied by Wainger et al. (2016). We analyzed the effects of both land types together because their proportions were negatively correlated (Fig. 2), which would make the effects of one land use obscure the effects of the other if they were tested separately as independent variables in alternate regression models of chlorophyll or nutrient concentration.

We did not analyze the effect of forested land together with the effects of developed land and cropland. Previous comparative watershed studies (cited above) have well documented that $\mathrm{N}$ and $\mathrm{P}$ discharges increase with higher cropland or developed land percentages and decrease with higher forest percentage. Furthermore, land use percentages are not independent (King et al. 2005). For upland areas (excluding tidal wetlands and water), the percentages of cropland and developed land together explain $91 \%$ of the variation in the percentage of forest among our 49 local watersheds. Adding forest to our regression models would add little explanatory power while confounding model interpretation because of the very high correlation among the independent variables (the problem of collinearity, Neter et al. 1990, Mason et al. 1991). The intercepts of models with only cropland and developed land as independent variables do provide estimates of the low concentrations expected in a subestuary with no cropland or developed land in its local watershed (Table 1).

\section{Effects of Land Use on Other Estuarine Responses}

Some comparative studies have related differences in biotic communities in estuaries to differences in land use composition of their watersheds. For the example, higher proportions of urban and agricultural land in the local watersheds of subestuaries were associated with increased abundance of the invasive reed P. australis in tidal wetlands (King et al. 2007; Sciance et al. 2016) and with reduced abundance of submerged aquatic vegetation $(\mathrm{SAV})$ in subtidal waters $(\mathrm{Li}$ et al. 2007; Patrick et al. 2014, 2016; Patrick and Weller 2015; Patrick et al. 2017). Comparative studies have also documented a negative association of urban land in watersheds with the diversity and abundance of benthic invertebrates and fish in estuaries (Dauer et al. 2000; Holland et al. 2004; King et al. 2005; Bilkovic et al. 2006; Kornis et al. 2017). The effects of agricultural lands were generally attributed to nutrient loading, while the effects of urban land may also be due to shoreline alterations or toxic contaminants.

\section{Hydrodynamic Factors}

Models relating watershed land use to water quality in lakes often incorporate variables to represent hydrodynamic characteristics. For example, Jones et al. (2004) found that TP concentration increased with the ratio of watershed area to lake area. Fraterrigo and Downing (2008) also incorporated this ratio into a measure of watershed transport capacity, which influenced the responses of TP and TN concentrations in lakes to watershed land use. Similarly, Wainger et al. (2016) found that the ratio of watershed area to estuary volume seemed to account for flushing of chlorophyll out of the estuary. We found that the ratio of watershed area to estuary area was positively correlated with TN, DIN, and NO3, probably reflecting the increase in $\mathrm{N}$ loads from the local watershed as the area ratio increases. We did not find an effect of area ratio on chlorophyll, possibly because the stimulation of phytoplankton growth by the $\mathrm{N}$ loads from the watershed was counteracted by flushing of chlorophyll out of the subestuary.

The unusually close match of NO3 concentrations inside and outside the Elk River (Fig. 8) may reflect enhanced mixing with water from the adjacent Chesapeake main stem due to the connection of the Chesapeake and Delaware Canal with the Elk River just down estuary of our sample sites. The dredged channel leading to the canal and the strong tidal currents running through the canal could help to draw main-stem water up the Elk River. In contrast, no significant effect of outside NO3 concentration on inside concentration was evident when we analyzed the subestuaries as a group.

In estuaries, salinity indicates the relative proportions of water from the land and the ocean. Wainger et al. (2016) found salinity to be a useful predictor of chlorophyll concentrations in the estuaries they compared. In waters outside our subestuaries, NO3 concentration decreased as salinity increased, indicating a watershed source (Fig. 7), but inside our subestuaries NH4 increased as salinity increased (Fig. 6), possibly due to ion exchange with adsorbed ammonium as described by Gardner et al. (1991). We also found a tendency for TP and PO4 concentrations to be elevated at 
salinities of 7-9 ppt (Fig. 7). We did not test the statistical significance of this pattern, but it might reflect release of $\mathrm{P}$ from terrigenous sediments stimulated by sulfate reduction at low salinities (Hartzell and Jordan 2012).

\section{Local Watershed vs. Adjacent Tidal Waters}

In contrast to lakes or streams, the inputs to estuaries from their watersheds are accompanied by exchanges with adjacent tidal waters outside of the estuary. For example, the Rhode River (one of the subestuaries in this study) receives most of its $\mathrm{P}$ from its local watershed but most of its $\mathrm{N}$ from exchanges with the adjacent water in the main stem of upper Chesapeake Bay (Jordan et al. 1991). Also, the lower York River estuary receives most of its organic matter inputs from exchanges with adjacent Chesapeake Bay waters while the upper York River estuary receives organic matter primarily from its local watershed (Lake and Brush 2015).

Our comparisons of water quality inside vs. outside the subestuaries were partly intended to test the relative importance of the local watershed versus exchanges with adjacent tidal waters. The statistically significant effects of local land use on TN, DIN, NH4, and chlorophyll $a$ concentrations inside the subestuaries and the lack of significant effects of outside concentrations together suggest that the local watershed land use is more important in controlling those concentrations (July-October) than exchange with the adjacent tidal waters. In contrast, the statistical link between inside and outside TP and PO4 concentrations suggests that imports from adjacent tidal waters as well as cropland in the watershed influence P concentration in the subestuaries. However, a correlation between inside and outside concentrations might also suggest that outside concentrations reflect exports from the subestuaries to the main stem. Therefore, we can only conclude that the control of TP and PO4 concentrations may be driven by processes at larger spatial scales than that of the individual subestuary.

\section{Nearshore Shallow Waters Have Distinct Water Quality}

Comparing the concentrations inside vs. outside the subestuaries highlights differences between nearshore shallow waters $(<2 \mathrm{~m}$ deep) and deeper waters off the mouths of the subestuaries (Fig. 1). Nearshore shallow waters are generally closer to watershed and intertidal sources and sinks for nutrients, and well-mixed shallows generally have more light available throughout the water column compared to the surface mixed layer of stratified waters (Kennish et al. 2014). Also, well-mixed shallow waters receive nutrients released from bottom sediments while stratified deep waters are cut off by the pycnocline from benthic nutrient inputs (Kennish et al. 2014). These differences could account for the stark contrasts in concentrations of nutrients and chlorophyll we observed between the shallow nearshore water inside the subestuaries and the surface of deeper waters outside the subestuaries. The higher light availability in shallower water probably accounts for the higher chlorophyll concentrations and lower nitrate concentrations inside the subestuaries than outside (Fig. 8). Denitrification in bottom sediments as well as uptake by autotrophs including submerged and intertidal vegetation could account for the lower nitrate concentrations (Kennish et al. 2014). Higher NH4 and TP concentrations inside than outside (Fig. 6) may reflect the contribution of $\mathrm{P}$ release from bottom sediments in the shallow water (e.g., Jordan et al. 1991). The differences in concentrations we observed inside vs. outside the subestuaries suggest that the subestuaries generally export TP, NH4, TKN, and chlorophyll to the adjacent waters while importing nitrate from adjacent waters.

\section{Summer-Fall Water Quality Is More Indicative of Eutrophication Than Spring}

Water quality changes seasonally in Chesapeake Bay and its subestuaries. Nitrate concentrations peak in winter and spring when watershed discharges of water and nitrate are highest and phytoplankton growth is limited by temperature and incident light (Fisher et al. 1992; Pennock and Sharp 1994). Phytoplankton blooms develop in spring and may be limited by P or Si (Fisher et al. 1992, 1999). In summer, nitrate concentrations decline as the phytoplankton biomass peaks and growth becomes limited by $\mathrm{N}$ because the rate of $\mathrm{P}$ release from the sediments increases (Jordan et al. 1991; Fisher et al. 1992; Gallegos and Jordan 1997; Gallegos et al. 1997). In our subestuaries, chlorophyll concentrations were generally highest in summer and early fall (Fig. 3). Thus, water quality conditions in summer and early fall seem more indicative of the degree of eutrophication in the subestuaries than are spring conditions. For this reason, we focused our analysis on the period from July-October. For similar reasons, Wainger et al. (2016) focused their estuarine comparisons on the period from May-August rather than comparing concentrations averaged throughout the year. Given the ephemeral nature of spring phytoplankton blooms and the potential for interannual variability in spring bloom intensity in subestuaries (e.g., Gallegos et al. 1997), it is possible that our April-June sampling missed spring blooms in many of subestuaries.

While it is clear that nitrate inputs to the subestuaries come from watershed sources, it is not clear from our July-October water quality measurements whether the dominant nitrate source is generally the local watershed of a subestuary or the watersheds of the larger Chesapeake tributaries such as the Susquehanna and Potomac rivers. The statistical significance of local land use in predicting subestuary nitrate concentration depended on which factors were included in the model. It seems likely that the importance of the local watershed differs 
among the subestuaries. NO3 in the Rhode River comes mainly from exchanges of water with upper Chesapeake (Jordan et al. 1991). But other subestuaries that are located further from the head of the Chesapeake Bay, have higher percentages of agricultural or developed land in their local watersheds or have higher ratios of watershed area to subestuary area than the Rhode River may get most of their NO3 from their local watersheds.

\section{Nitrogen vs. Phosphorus Limitation}

The effects of land use on chlorophyll $a$ and forms of $\mathrm{N}$ and $\mathrm{P}$ suggest that $\mathrm{N}$ rather than $\mathrm{P}$ limited chlorophyll production in our subestuaries from July-October because P concentrations increased with cropland but not with developed land (Fig. 4, Tables 1 and 2), while TN, DIN, and chlorophyll increased with both land types (Figs. 3 and 4, Table 1). However, $\mathrm{N}$ or $\mathrm{P}$ limitation of phytoplankton growth is sometimes inferred from ratios of DIN/DIP or TN/TP, with ratios above $16 \mathrm{im}$ plying P limitation and ratios below 16 implying $\mathrm{N}$ limitation (e.g., Downing 1997). Taking PO4 to represent DIP, the median of the DIN/DIP ratios of all our samples was 37 (5th and 95th percentiles $=3.2$ and 161), while the median of the $\mathrm{TN} /$ TP ratio was 18 (8.8-29). The medians of both of these ratios are above 16 , implying P limitation, but the ratios vary widely above and below 16 . We found no significant effects of cropland, developed land, area ratio, or salinity on DIN/DIP or TN/ TP or the logarithms of these ratios.

Several studies suggest that $\mathrm{N}$ limitation is more common than P limitation in coastal marine ecosystems (e.g., see Howarth and Marino 2006). Studies throughout Chesapeake Bay have indicated that $\mathrm{P}$ may be limiting in spring and in locations where salinity is low (e.g., Fisher et al. 1992, 1999). Spring blooms in the Rhode River subestuary were limited by either $\mathrm{P}$ or $\mathrm{N}$ in different years (Gallegos et al. 1997). Release of $\mathrm{P}$ from terrigenous sediments due to sulfate reduction in low salinity zones of estuaries could prevent $\mathrm{P}$ limitation in summer and early fall (Jordan et al. 1991, 2008). Given the variability of nutrient limitation in estuaries, management of both $\mathrm{N}$ and $\mathrm{P}$ seems prudent (e.g., Paerl 2009).

It has been suggested that that $\mathrm{N}$ fixation should prevent $\mathrm{N}$ limitation in estuaries as has been demonstrated for lakes with long-term whole-lake nutrient manipulations (Schindler et al. 2008). It would be more difficult to experimentally manipulate $\mathrm{N}$ and $\mathrm{P}$ supplies in whole estuaries than in lakes, but nutrient pollution and mitigation of nutrient pollution in different estuaries may have generated enough examples of contrasting $\mathrm{N}$ and $\mathrm{P}$ supplies to provide a quasi-experimental test of which element is limiting. Comparing estuaries to provide a wholeecosystem test of nutrient limitation would require a more rigorous analysis of $\mathrm{N}$ and $\mathrm{P}$ input rates to the estuaries than was possible in our study.

\section{Management Implications}

Our study has important implications for understanding and managing nutrient pollution in Chesapeake Bay and estuaries in general. First, in Chesapeake Bay subestuaries, cropland and developed land in local watersheds significantly increase local concentrations of nutrients and chlorophyll. Local human land use also has negative impacts on biota in subestuaries (see citations above) including submerged aquatic vegetation, an important indicator of coastal eutrophication (Orth et al. 2017). Eutrophication and its negative ecological impacts cannot be blamed only on loads from the major tributaries (such as the Susquehanna and Potomac rivers) and the human activities there; so efforts to manage and restore shallow estuarine waters must address local land use effects. Second, water quality is very different in nearshore shallow waters than in adjacent stratified estuarine waters. Sampling outside of the mouth of the subestuary is not sufficient to characterize the shallow water habitats for submerged vegetation and other littoral biota. Therefore, management plans built on data and models derived from sampling away from the shoreline only may not succeed. Third, much can be learned from nearshore sampling even with an average of only ten samples from each estuarine system during the season of maximum chlorophyll concentration. Fourth, comparing multiple small estuaries with watersheds of contrasting land use composition can lead to insights about sources and effects of $\mathrm{N}$ and $\mathrm{P}$, which could help target management efforts.

Acknowledgements Funding for this research was provided by award number NA09NOS4780214 from the National Oceanic and Atmospheric Administration (NOAA), Center for Sponsored Coastal Ocean Research (CSCOR). A Research Experiences for Undergraduates (REU) grant from National Science Foundation (NSF) supported Shelby Paschal who helped with field and lab work in 2014. Meghan Williams provided land cover summaries. This is publication \# 17-002 of the NOAA/ CSCOR Mid-Atlantic Shorelines project.

Open Access This article is distributed under the terms of the Creative Commons Attribution 4.0 International License (http://creativecommons. org/licences/by/4.0/), which permits use, duplication, adaptation, distribution and reproduction in any medium or format, as long as you give appropriate credit to the original author(s) and the source, provide a link to Creative Commons license and indicate if changes were made.

\section{References}

APHA (American Public Health Association). 1995. Standard methods for the examination of water and wastewater. 19th ed. Washington, DC: APHA.

Beaulac, M.N., and K.H. Reckhow. 1982. An examination of land usenutrient export relationships. Water Resources Bulletin 18: 10131022. 
Beck, M.W., K.L. Heck Jr., K.W. Able, L. Daniel, D.B. Eggleston, B.M. Gillanders, B. Halpern, et al. 2001. The identification, conservation, and management of estuarine and marine nurseries for fish and invertebrates. Bioscience 51: 633-641.

Bilkovic, D.M., M. Roggero, C.H. Hershner, and K.H. Havens. 2006. Influence of land use on macrobenthic communities in nearshore estuarine habitats. Estuaries and Coasts 29: 1185-1195. doi:10. 1007/BF02781819.

Boesch, D.F., R.B. Brinsfield, and R.E. Magnien. 2001. Chesapeake Bay eutrophication: scientific understanding, ecosystem restoration, and challenges for agriculture. Journal of Environmental Quality 30: 303-320.

Bologna, P.A.X., and K.L. Heck Jr. 1999. Macrofaunal associations with seagrass epiphytes: relative importance of trophic and structural characteristics. Journal of Experimental Marine Biology and Ecology 242: 21-39.

Brady, D.C., and T.E. Targett. 2013. Movement of juvenile weakfish Cynoscion regalis and spot Leiostomus xanthurus in relation to diel-cycling hypoxia in an estuarine tidal tributary. Marine Ecology Progress Series 491: 199-219. doi:10.3354/meps10466.

Burnham, K.P., and D.R. Anderson. 2002. Model selection and multimodel inference. Second ed. New York, New York: Springer.

Caraco, N.F., and J.J. Cole. 1999. Human impact on nitrate export: an analysis using major world rivers. Ambio 28: 167-170.

Castro, M.S., C.T. Driscoll, T.E. Jordan, W.G. Reay, and W.R. Boynton. 2003. Sources of nitrogen to estuaries in the United States. Estuaries 26: 803-814.

Cerco, C.F., B. Bunch, M.A. Cialone, and H. Wang. 1994. Hydrodynamics and eutrophication model study of Indian River and Rehoboth Bay, Delaware. Technical Report EL-94-5 for U.S. Environmental Protection Agency, Region III, Delaware Department of Natural Resources and Environmental Control, and U.S. Army Engineer District, Philadelphia. 262 pages.

Clark, K.L., G.M. Ruiz, and A.H. Hines. 2003. Diel variation in predator abundance, predation risk and prey distribution in shallow-water estuarine habitats. Journal of Experimental Marine Biology and Ecology 287: 37-55.

Cloern, J.E. 2001. Our evolving conceptual model of the coastal eutrophication problem. Marine Ecology Progress Series 210: 223-253.

Conley, D.J., H.W. Paerl, R.W. Howarth, D.F. Boesch, S.P. Seitzinger, K.E. Havens, C. Lancelot, and G.E. Likens. 2009. Controlling eutrophication: nitrogen and phosphorus. Science 323: 1014-1015.

Dauer, Daniel M., Stephen B. Weisberg, and J. Ananda Ranasinghe. 2000. Relationships between benthic community condition, water quality, sediment quality, nutrient loads, and land use patterns in Chesapeake Bay. Estuaries 23: 80-96.

Deegan, L.A., D.S. Johnson, R.S. Warren, B.J. Peterson, J.W. Fleeger, S. Fagherazzi, and W.M. Wollheim. 2012. Coastal eutrophication as a driver of salt marsh loss. Nature 490 Nature Publishing Group: 388 392. doi:10.1038/nature11533.

Dennison, W.C., J.E. Thomas, C.J. Cain, T.J.B. Carruthers, M.R. Hall, R.V. Jesien, C.E. Wazniak, and D.E. Wilson. 2009. Shifting sands: Environmental and cultural change in Maryland's coastal bays. Cambridge, MD: IAN Press, University of Maryland Center for Environmental Science.

Diaz, R.J., and R. Rosenberg. 2008. Spreading dead zones and consequences for marine ecosystems. Nature 321: 926-929.

Dittel, A.I., A.H. Hines, G.M. Ruiz, and K.K. Ruffin. 1995. Effects of shallow water refuge on behavior and density-dependent mortality of juvenile blue crabs in Chesapeake Bay. Bulletin of Marine Science 57: 902-916.

Doney, S.C. 2010. The growing human footprint on coastal and openocean biogeochemistry. Science 328: 1512-1516.

Downing, J.A. 1997. Marine nitrogen:phosphorus stoichiometry and the global N:P cycle. Biogeochemistry 37: 237-252.
Edgar, G.J. 1990. The influence of plant structure on the species richness, biomass and secondary production of macrofaunal assemblages associated with Western Australian seagrass beds. Journal of Experimental Marine Biology and Ecology 137: 215-240.

Edgar, G.J., and C. Shaw. 1995. The production and trophic ecology of shallow-water fish assemblages in southern Australia III. General relationships between sediments, seagrasses, invertebrates and fishes. Journal of Experimental Marine Biology and Ecology 194: 107131.

Erwin, R. Michael. 1996. Dependence of waterbirds and shorebirds on shallow-water habitats in the mid-Atlantic coastal region: an ecological profile and management recommendations. Estuaries 19: 213. doi:10.2307/1352226.

Eshleman, K.N., and R.D. Sabo. 2016. Declining nitrate-N yields in the Upper Potomac River Basin: what is really driving progress under the Chesapeake Bay restoration? Atmospheric Environment 146: 280-289.

Fisher, T.R., E.R. Peele, J.W. Ammerman, and L.W. Harding Jr. 1992. Nutrient limitation of phytoplankton in Chesapeake Bay. Marine Ecology Progress Series 82: 51-63.

Fisher, T.R., A.B. Gustafson, K. Sellner, R. Lacouture, L.W. Haas, R.L. Wetzel, R. Magnien, D. Everitt, B. Michael, and R. Karrh. 1999. Spatial and temporal variation of resource limitation in Chesapeake Bay. Marine Biology 133: 763-778.

Fraterrigo, J.M., and J.A. Downing. 2008. The influence of land use on lake nutrients varies with watershed transport capacity. Ecosystems 11: $1021-1034$.

Fry, J., G. Xian, S. Jin, J. Dewitz, C. Homer, L. Yang, C. Barnes, H. Herold, and J. Wickham. 2011. Completion of the 2006 National Land Cover Database for the conterminous United States. Photogrammetric Engineering and Remote Sensing 77: 858-864.

Gallegos, C.L., and T.E. Jordan. 1997. Seasonal progression of factors limiting phytoplankton pigment biomass in the Rhode River estuary, Maryland (USA). I. Controls of phytoplankton growth. Marine Ecology Progress Series 161: 185-198.

Gallegos, C.L., T.E. Jordan, and D.L. Correll. 1997. Interannual variability in spring bloom timing and magnitude in the Rhode River, Maryland (USA): observations and modeling. Marine Ecology Progress Series 154: 27-40.

Gardner, W.S., S.P. Seitzinger, and J.M. Malczyk. 1991. The effects of sea salts on the forms of nitrogen released from estuarine and freshwater sediments: does ion pairing affect ammonium flux? Estuaries 14: $157-166$.

Gemesi, Z., J.A. Downing, R.M. Cruse, and P.F. Anderson. 2011. Effects of watershed configuration and composition on downstream lake water quality. Journal of Environmental Quality 40: 517-527.

Glibert, P.M., C.E. Wazniak, M.R. Hall, and B. Sturgis. 2007. Seasonal and interannual trends in nitrogen and brown tide in Maryland's coastal bays. Ecological Applications 17: S79-S87.

Greene, C.M., K. Blackhart, J. Nohner, A. Candelmo, and D.M. Nelson. 2015. A national assessment of stressors to estuarine fish habitats in the contiguous USA. Estuaries and Coasts 38: 782-799.

Hagy, J.D., W.R. Boynton, C.W. Keefe, and K.V. Wood. 2004. Hypoxia in Chesapeake Bay, 1950-2001: Long-term change in relation to nutrient loading and river flow. Estuaries 27: 634-658.

Hartzell, J.L., and T.E. Jordan. 2012. Shifts in the relative availability of phosphorus and nitrogen along estuarine salinity gradients. Biogeochemistry 107: 489-500. doi:10.1007/s10533-010-9548-9.

Holland, A.F., D.M. Sanger, C.P. Gawle, S.B. Lerberg, M.S. Santiago, G.H.M. Riekerk, L.E. Zimmerman, G.I. Scott. 2004. Linkages between tidal creek ecosystems and the landscape and demographic attributes of their watersheds. Journal of Experimental Marine Biology and Ecology 298(2): 151-178.

Homer, C.G., J.A. Dewitz, L. Yang, S. Jin, P. Danielson, G. Xian, J. Coulston, N.D. Herold, J.D. Wickham, and K. Megown. 2015. 
Completion of the 2011 National Land Cover Database for the conterminous United States - representing a decade of land cover change information. Photogrammetric Engineering and Remote Sensing 81: 345-354.

Howarth, R.W., and R. Marino. 2006. Nitrogen as the limiting nutrient for eutrophication in coastal marine ecosystems: evolving views over three decades. Limnology and Oceanography 51: 364-376.

Howarth, R.W., G. Billen, D. Swaney, A. Townsend, N. Jaworski, K. Lajtha, J.A. Downing, R. Elmgren, N. Caraco, T. Jordan, F. Berendse, J. Freney, V. Kudeyarov, P. Murdoch, and Zhao-liang Zhu. 1996. Riverine inputs of nitrogen to the North Atlantic Ocean: fluxes and human influences. Biogeochemistry 35: 75-139.

Howarth, R., F. Chan, D.J. Conley, J. Garnier, S.C. Doney, R. Marino, and G. Billen. 2011. Coupled biogeochemical cycles: eutrophication and hypoxia in temperate estuaries and coastal marine ecosystems. Frontiers in Ecology and the Environment 9: 18-26.

Jeffrey, S.W., and G.F. Humphrey. 1975. New spectrophotometric equation for determining chlorophyll a, b, c', and cz in higher plants, algae, and natural phytoplankton. Biochemie und Physiologie der Pflanzen 167: 191-194.

Jones, J.R., M.F. Knowlton, D.V. Obrecht, and E.A. Cook. 2004. Importance of landscape variables and morphology on nutrients in Missouri reservoirs. Canadian Journal of Fisheries and Aquatic Sciences 61: 1503-1512.

Jordan, T.E., D.L. Correll, J. Miklas, and D.E. Weller. 1991. Nutrients and chlorophyll at the interface of a watershed and estuary. Limnology and Oceanography 36: 251-267.

Jordan, T.E., D.L. Correll, and D.E. Weller. 1997a. Effects of agriculture on discharges of nutrients from coastal plain watersheds of Chesapeake Bay. Journal of Environmental Quality. 26: 836-848.

Jordan, T.E., D.L. Correll, and D.E. Weller. 1997b. Nonpoint source discharges of nutrients from Piedmont watersheds of Chesapeake Bay. Journal of the American Water Resources Association 33: 631-645.

Jordan, T.E., D.L. Correll, and D.E. Weller. 1997c. Relating nutrient discharges from watersheds to land use and stream flow variability. Water Resources Research 33: 2579-2590.

Jordan, T.E., D.E. Weller, and D.L. Correll. 2003. Sources of nutrient inputs to the Patuxent River estuary. Estuaries 26: 226-243.

Jordan, T.E., J.C. Cornwell, W.R. Boynton, and J.T. Anderson. 2008. Changes in phosphorus biogeochemistry along an estuarine salinity gradient: The iron conveyer belt. Limnology and Oceanography 53: 172-184.

Kemp, W.M., W.R. Boynton, J.E. Adolf, D.F. Boesch, W.C. Boicourt, G. Brush, J.C. Cornwell, T.R. Fisher, P.M. Glibert, J.D. Hagy, L.W. Harding, E.D. Houde, D.G. Kimmel, W.D. Miller, R.I.E. Newell, M.R. Roman, E.M. Smith, and J.C. Stevenson. 2005. Eutrophication of Chesapeake Bay: historical trends and ecological interactions. Marine Ecology-Progress Series 303: 1-29.

Kennish, M.J., M.J. Brush, and K.A. Moore. 2014. Drivers of change in shallow coastal photic systems: an introduction to a special issue. Estuaries and Coasts 37 (Suppl 1): S3-S19.

Kettenring, K.M., D.F. Whigham, E.L.G. Hazelton, S.K. Gallagher, and H.M. Weiner. 2015. Biotic resistance, disturbance, and mode of colonization impact the invasion of a widespread, introduced wetland grass. Ecological Applications 25: 466-480.

King, E.J. 1932. The colorimetric determination of phosphorus. Biochemistry Journal 26: 292-297.

King, R.S., M.E. Baker, D.F. Whigham, T.E. Jordan, P.F. Kazyak, and M.K. Hurd. 2005. Spatial considerations for linking watershed land cover to ecological indicators in streams. Ecological Applications 15: $137-153$.

King, R.S., W.V. Deluca, D.F. Whigham, and P.P. Marra. 2007. Threshold effects of coastal urbanization on Phragmites australis (common reed) abundance and foliar nitrogen in Chesapeake Bay. Estuaries and Coasts 30: 469-481. doi:10.1007/BF02819393Lake.
Kornis, M.S., D. Brietburg, R. Balouskus, D.M. Bilkovic, L.A. Davias, S. Giordano, K. Heggie, A.H. Hines, J.M. Jacobs, T.E. Jordan, R.S. King, C.J. Patrick, R.D. Seitz, H. Soulen, T.E. Targett, D.E. Weller, D.F. Whigham, and J. Uphoff Jr. 2017. Linking the abundance of estuarine fish and crustaceans in nearshore waters to shoreline hardening and land cover. Estuaries and Coasts. doi:10.1007/s12237017-0213-6.

Lake, S.J., and M.J. Brush. 2015. Contribution of nutrient and organic matter sources to the development of periodic hypoxia in a tributary estuary. Estuaries and Coasts 38: 2149-2171.

Langley, J.A., K.L. Mckee, D.R. Cahoon, J.A. Cherry, and J.P. Megonigal. 2009. Elevated CO2 stimulates marsh elevation gain, counterbalancing sea-level rise. Proceedings of the National Academy of Sciences of the United States of America 106: 61826186.

Li, X., D.E. Weller, C.L. Gallegos, T.E. Jordan, and H.-C. Kim. 2007. Effects of watershed and estuarine characteristics on the abundance of submerged aquatic vegetation in Chesapeake Bay subestuaries. Estuaries and Coasts 30: 840-854. doi:10.1007/BF02841338.

Liu, Z.J., D.E. Weller, D.L. Correll, and T.E. Jordan. 2000. Effects of land cover and geology on stream chemistry in watersheds of Chesapeake Bay. Journal of the American Water Resources Association 36: 1349-1365.

Martin, D.F. 1972. Marine chemistry. Vol. 1. New York: Marcel Dekker.

Mason, C.H. and W.D. Perreault, Jr. 1991. Collinearity, power, and interpretation of multiple regression analysis. Journal of Marketing Research 28: 268-280.

Miller, D.C., R.J. Geider, and H.L. MacIntyre. 1996. Microphytobenthos: the ecological role of the "secret garden" of unvegetated, shallowwater marine habitats. II. Role in sediment stability and shallowwater food webs. Estuaries 19: 202-212.

Neter, J., W. Wasserman, and M.H. Kutner. 1990. Applied linear statistical models. Burr Ridge: Richard D. Irwin, Inc., QA278.2.N47 1990.

Nixon, S.W. 1995. Coastal marine eutrophication: a definition, social causes, and future consequences. Ophelia 41: 199-219.

Olson, M. 2012. Guide to Using Chesapeake Bay Program Water Quality Monitoring Data. M. Mallonee. Annapolis, MD, Chesapeake Bay Program.

Orth, R.J., T.J.B. Carruthers, W.C. Dennison, C.M. Duarte, J.W. Fourqurean, K.L. Heck, A.R. Hughes, G.A. Kendrick, W.J. Kenworthy, S. Olyarnik, F.T. Short, M. Waycott, and S.L. Williams. 2006. A global crisis for seagrass ecosystems. Bioscience 56: 987-996.

Orth, R.J., M.R. Williams, S.R. Marion, D.J. Wilcox, T.J.B. Carruthers, K.A. Moore, W.M. Kemp, W.C. Dennison, N. Rybicki, P. Bergstrom, and R.A. Batiuk. 2010. Long-term trends in submersed aquatic vegetation (SAV) in Chesapeake Bay, USA, related to water quality. Estuaries and Coasts 33: 1144-1163.

Orth, R. J., W. C. Dennison, J. S. Lefcheck, C. Gurbisz, M. P. Hannam, J. Keisman, J. B. Landry, K. A. Moore, R. R. Murphy, C. J. Patrick, J. M. Testa, D. E. Weller, and D. J. Wilcox. 2017. Submersed aquatic vegetation in Chesapeake Bay: sentinel species in a changing world. Bioscience.

Paerl, H. W. 2009. Controlling eutrophication along the freshwater-marine continuum: Dual nutrient ( $\mathrm{N}$ and $\mathrm{P}$ ) reductions are essential. Estuaries and Coasts 32: 593-601. doi:10.1007/s12237-009-9158-8.

Paerl, H.W., N.S. Hall, B.L. Peierls, and K.L. Rossignol. 2014. Evolving paradigms and challenges in estuarine and coastal eutrophication dynamics in a culturally and climatically stressed world. Estuaries and Coasts 37: 243-258.

Paterson, A.W., and A.K. Whitfield. 2000. Do shallow-water habitats function as refugia for juvenile fishes? Estuarine, Coastal and Shelf Science 51: 359-364. doi:10.1006/ecss.2000.0640.

Patrick, C.J., and D.E. Weller. 2015. Interannual variation in submerged aquatic vegetation and its relationship to water quality in subestuaries of Chesapeake Bay. Marine Ecology Progress Series 537: 121-135. doi:10.3354/meps11412. 
Patrick, C.J., D.E. Weller, X. Li, M. Ryder, and M. 2014. Effects of shoreline alteration sand other stressors on submerged aquatic vegetation in subestuaries of Chesapeake Bay and the mid-Atlantic coastal bays. Estuaries and Coasts 37: 1516-1531.

Patrick, C.J., D.E. Weller, and M. Ryder. 2016. The relationship between shoreline armoring and adjacent submerged aquatic vegetation in Chesapeake Bay and nearby Atlantic coastal bays. Estuaries and Coasts 39: 158-170.

Patrick, C.J., D.E. Weller, R.J. Orth, D.E. Wilcox, and M.P. Hannam. 2017. Land use and salinity drive changes in SAV abundance and community composition. Estuaries and Coasts. doi:10.1007/ s12237-017-0250-1.

Pennock, J.R., and J.H. Sharp. 1994. Temporal alternation between lightand nutrient-limitation of phytoplankton production in a coastal plain estuary. Marine Ecology Progress Series 111: 275-288.

Prosser, D.J., T.E. Jordan, R.D. Seitz, D.E. Weller, D.F. Whigham, and J.L. Nagel. This issue. Impacts of coastal land use and shoreline armoring on estuarine ecosystems: an introduction to a special issue. Estuaries and Coasts (in review).

R Development Core Team. 2014. R: a language and environment for statistical computing. Vienna: R Foundation for Statistical Computing http://www.R-project.org/.

Schindler, D.W., R.E. Hecky, D.L. Findlay, M.P. Stainton, B.R. Parker, M.J. Paterson, K.G. Beaty, M. Lyng, and S.E.M. Kasian. 2008. Eutrophication of lakes cannot be controlled by reducing nitrogen input: results of a 37-year whole-ecosystem experiment. Proceedings of the National Academy of Sciences 105: 1125411258.

Sciance, M.B., C.J. Patrick, D.E. Weller, M.N. Williams, M.K. McCormick, and E.L.G. Hazelton. 2016. Local and regional disturbances associated with the invasion of Chesapeake Bay marshes by the common reed Phragmites australis. Biological Invasions. 18: 2661-2677. doi:10.1007/s10530-016-1136-z.

Silliman, B.R., and M.D. Bertness. 2004. Shoreline development drives invasion of Phragmites australis and the loss of plant diversity on New England salt marshes. Conservation Biology 18: 1424-1434.
Strickland, J.D., and T.R. Parsons. 1972. A practical handbook of seawater analysis. $2^{\text {nd }}$ edition. Bulletin of the Fisheries Research Board of Canada 167: 1-310.

Tyler, R.M., D.C. Brady, and T.E. Targett. 2009. Temporal and spatial dynamics of diel-cycling hypoxia in estuarine tributaries. Estuaries and Coasts 32: 123-145. doi:10.1007/s12237-008-9108-x.

USEPA (U. S. Environmental Protection Agency). 2010. Chesapeake Bay total maximum daily load for nitrogen, phosphorus and sediment. http://www.epa.gov/sites/production/files/2014-12/ documents/cbay_final_tmdl_exec_sum_section_1_through_3 final_0.pdf. Last accessed 3 Feb2016.

Wainger, L., Y. Hao, K. Gazenski, and W. Boynton. 2016. The relative influence of local and regional environmental drivers of algal biomass (chlorophyll-a) varies by estuarine location. Estuarine, Coastal and Shelf Science 178: 65-76.

Waycott, M., C.M. Duarte, T.J.B. Carruthers, R.J. Orth, W.C. Dennison, S. Olyarnik, A. Calladine, et al. 2009. Accelerating loss of seagrasses across the globe threatens coastal ecosystems. Proceedings of the National Academy of Sciences of the United States of America 106: 12377-12381.

Wazniak, C.E., M.R. Hall, T.J.B. Carruthers, B. Stugis, W.C. Dennison, and Robert J. Orth. 2007. Linking water quality to living resources in a mid-Atlantic lagoon system, USA. Ecological Applications 17: S64-S78.

Weller, D.E., and M.E. Baker. 2014. Cropland riparian buffers throughout Chesapeake Bay watershed: spatial patterns and effects on nitrate loads delivered to streams. Journal of the American Water Resources Association 50: 696-715.

Weller, D.E., T.E. Jordan, D.L. Correll, and Z.J. Liu. 2003. Effects of land-use change on nutrient discharges from the Patuxent River watershed. Estuaries 26: 244-266.

Weller, D.E., M.E. Baker, and T.E. Jordan. 2011. Effects of riparian buffers on nitrate concentrations in watershed discharges: new models and management implications. Ecological Applications 21: 1679-1695. 